\title{
Morphometry Characteristics of Riverbed Sediment Grains as Basic Indicator Management of River Valley Environment (Case Study of Bogowonto River, Central Java)
}

\author{
Suprapto Dibyosaputro \\ Faculty of Geography, Universitas Gadjah Mada \\ Corresponding email: praptodibyo@gmail.com
}

\begin{abstract}
This research aims to propose the usage of riverbed sediment grains roundness/flatness as a basic indicator of river valley management. It is based on the evaluation of anomalous morphometry condition of sediment grains and valley condition along the river as one indicator of the stability of the riverbank of the river valley. This stability expresses the physical condition of the river valleys. In this paper, we provide a methodological explanation as well as a case study in Bogowonto River. Analysis of the morphometry of sediment grain on riverbed from upstream to downstream as well as the relationship between the distance of the upstream and morphometry of sediment grains along Bogowonto River was conducted. Finally, we evaluated the anomalous condition as an indicator of the different environmental condition of the riverbank. We conducted three stages survey processes: preparation, fieldwork, and post-fieldwork. The preparation phase includes site selection, the depiction of the main river channel of Bogowonto River, and the determination of the sample location. The distance between each sampling site was $5 \mathrm{~km}$ along Bogowonto River. The results show that there is anomalous morphometry of sediment grains found in the study area. The reason is that the channel of the segment of the river flowing over rocky riverbed of breccia along the $7.5 \mathrm{~km}$, with hard and sharps edge grained of rock particles. This is accompanied by landslide the occurrence in the upper segment of the river. This is why the value of roundness and flatness indexes are changed significantly become lower value than the previous segment. This condition can be implemented to be used as an indicator to basic management of landslide along a certain segment which indicated by the changing in roundness and flatness index values of the sediment grains.
\end{abstract}

Keywords: river valley management, sediment grain, sediment roundness, Bogowonto River

\begin{abstract}
Abstrak
Penelitian ini bertujuan untuk mengusulkan penggunaan butir dasar sungai sedimen kebulatan / kepipihan sebagai indikator dasar dari manajemen lembah sungai. Hal ini didasarkan pada evaluasi kondisi anomali morfometri butir sedimen dan kondisi lembah di sepanjang sungai sebagai salah satu indikator stabilitas tebing sungai. Stabilitas ini mengungkapkan kondisi fisik lembah-lembah sungai. Dijelaskan pula metodologi serta studi kasus di Sungai Bogowonto dijelaskan serta analisis morfometri dari butir sedimen di dasar sungai dari hulu ke hilir serta hubungan antara jarak dari hulu dan morfometri butir sedimen di sepanjang Sungai Bogowonto. Akhirnya, kami mengevaluasi kondisi anomali sebagai indikator kondisi lingkungan yang berbeda dari tepi sungai. Kami melakukan tiga tahap proses survei: persiapan, kerja lapangan, dan pasca-kerja lapangan. Tahap persiapan meliputi pemilihan lokasi, penggambaran saluran sungai utama Sungai Bogowonto, dan penentuan lokasi sampel. Jarak antara setiap lokasi pengambilan sampel adalah $5 \mathrm{~km}$ di sepanjang Sungai Bogowonto. Hasil penelitian menunjukkan bahwa ada anomali morfometri butir sedimen yang ditemukan di daerah penelitian. Alasannya adalah bahwa segmen alur sungai mengalir di atas sungai berbatu breksi sepanjang 7,5 km, dengan tepi keras dan tajam berbutir partikel batu. Kondisi ini disertai dengan longsor terjadinya di segmen atas sungai. Inilah sebabnya mengapa nilai indeks kebulatan dan kepipihan berubah secara signifikan menjadi lebih rendah dari segmen sebelumnya. Kondisi ini dapat diimplementasikan untuk digunakan sebagai indikator untuk manajemen dasar longsor sepanjang segmen tertentu yang ditunjukkan oleh perubahan dalam kebulatan dan indeks kepipihan nilai butir sedimen.
\end{abstract}

Kata kunci: manajemen lembah sungai, butir sedimen, sedimen kebulatan, Sungai Bogowonto 


\section{Introduction}

River is one of geographical feature that has dynamic characteristic. The existence of the channel and the river valley will determine and are determined by the morphology of the surrounding landscape along the varies river channel, from upstream to downstream. Such variabilities occur not only in the river but also in the area around the river. It shows that the river channel is the site where the processes of erosion occur (riverbank and riverbed). It is also as a transport media of sedimentary materials and a sedimentation area resulted from erosion and landslides along the river. The dynamic movement of the of materials in the river basins that alternated from material erosion of riverbed and riverbank, the material transport from the erosion and the deposition of material are all three phases as a single activity called three phases of a single activity (Thornburry, 1958; Morisawa, 1968; Darrel et al., 2001). Each phase is due to the difference in the power of water exertion in river basins in the form of stream competence and stream capacity (Morisawa, 1968; Dunatnu, et .al., 2011).

Geomorphologically, channels and fluvial river valleys from the upstream to downstream of river have gradual change both in valley shape and river gradient. The upstream generally has a straight shape whereas the valley and the riverbed are gradually narrower. Similarly, gradient of the upstream is higher and gradually become smaller in the downstream (Barrett 2010; Mark, 2014). Stream competency is the largest particles that can be able to be moved along the river bed at various river discharge while the stream capacity is the total amount of river sediment that can be able to be transported (Morisawa, 1968; Ro Charlton, 2008). Due to its high velocity, the stream in the river channel enables to release sediment materials, although that it is still in the form of aggregate (in situ) to become loose materials and transport them to the downstream.

Both of the processes are controlled by variation of water discharge and the river gradient as well regime of total sediment materials. Those processes area generally have significant differences between process at the upstream gradient (steep-slope), the middle part (gentle slope) and the downstream (gentle-flat). If the flow capacity to release and transport is getting lower, the channel will be no longer able to load material and finally, the sediment materials are deposited at the downstream as bed material. According to the function river channel, from the upstream to the downstream of the river can be divided into 3 (three) function zones, namely supply zone, transporter zone and consumer zone (Verstappen, 1983; Ro Charlton, 2008).

In these three zones, the gradation of sediment grains was transported in terms of grain size, grain shape, roundness and flatness of sediment grains) (Bloff, et.al., 2008; Adamzak et al., 2011, Koeli and Debasish, 2014). The grain morphometry naturally will follow the natural law for the grain size, grain shape, roundness and flatness levels of sediment grains. At the upstream channel, the morphometry of sediment grains are ranging in size from large, irregularly shaped, not round and not flat, but they are gradually smaller in size, more regular rounder and flatter in shape at the lower course (Strahler, AN, and AH Strahler, 1978; Baotian, 2015). A geologist, Krumbein (1941 b), is the first to reveal that sediment grain roundness is determined by transport distance, river velocity, and speed of particle movement. Therefore, Krumben (1941a) formulates a mathematical formula that shows a relationship between roundness of riverbed materials and transport distance from a specified point at the upper course to lower course. Roundness and flatness have proven to be useful properties of particles (greater than sand size) when investigating the transport and deposition of sedimentary material. Roundness refers to the sharpness of the corners and edges of a grain. Roundness was defined by Wadell (1932 in Gunther, 2006) as the ratio between the average radius of curvature of the corners with the radius of the largest inscribed circle. Flatness refers to the flat of grains stated by Wadell (1932 in Gunther, 2006). He defined flatness index as a ratio between the sum of length (A) and width 
(B) of grain divided by the two times of thick (2C) of grain. Flatness measures the degree to the flatness of particles vary from equant to flat. From that formula, it can be stated that the rate of change of roundness is a function of the transport distance so that at certain distances will be different in roundness (limiting roundness). The results of all the research shows that the greater the distance transported the sediment particles, the higher the roundness index value of particles sediment grains. Also, the greater the distance transported sediment particles, the smaller will be the value of the index flatness sediment particles.

In some cases there are some anomalous of morphometry value of grains at some places along the river channel from upper to lower course. It can be used as an indicator that the anomalous changes in the index value of the morphometry sediment grains (roundness and flatness) due to the addition of new material from the branches of the river or the addition of new material from the walls of the valley and riverbed erosion and avalanches in the walls of the river valley, as well as differences in the bedrock of the river channel. In the other words, anomalous sediment grain morphometry index value is due to the instability of the river valley and channel caused by landslides of the riverbank, erosion of the river valley and the riverbed, as well as the differences of rock bottom of the river. Therefore, index anomalous sediment grains (roundness and flatness) can be seen from the deviation index morphometry value of the normal conditions on the graph that describes the relationship between the distances from the upstream to downstream. Finally, this deviation phenomena can be used as an indicator for river management in relation to the maintenance of an environment channel and river valleys.

This research study aims to propose the usage of the index of sediment grain as indicator of river management. It used a case study that emphasizes only to the main Bogowonto River, excluding the river branches that entering into the main channel of Bogowonto. It is based on the reason that the main river sediment dynamics of Bogowonto do not disturbed and mixed by sediment materials of rivers derived from Merapi Volcano. Thus the results of research will be obtained integrity of the processes of the hydrology and geomorphology processes, which work mainly caused by Bogowonto river only.

\section{Research Method}

The survey methods used in this research both field and laboratory surveys with three phases namely the preparatory, field work, and postfieldwork phases.

In the preparation phase consist of the selection of research areas, It is determined that Bogowonto river is the research area since there are no any added materials from outside of the river (i.e lava of Merapi Volcano) so that the materials flow along the river only come from the upstream of Bogowonto watershed. Figure 1 displays Bogowonto River and its branches as the research areas. Afterward, sample points along Bogowonto river are determined by systematic sampling and the interval for each point is $5 \mathrm{~km}$. Materials such as a map of earth surface and Geo Eye imagery should be prepared as well. Furthermore, research tools used in this research was prepared include: Yalon, Meter Scale, Abney Level, a tool to measure radius of a stone circle, GPS, a set computer and Arc GIS software 9.3, camera and stationery.

On field work phase, primary data collection include: measurements of cross sections and river gradient, sampling of riverbed sediment grains as much as 100 grains by zig zag stepping as presented in Figure 2. 


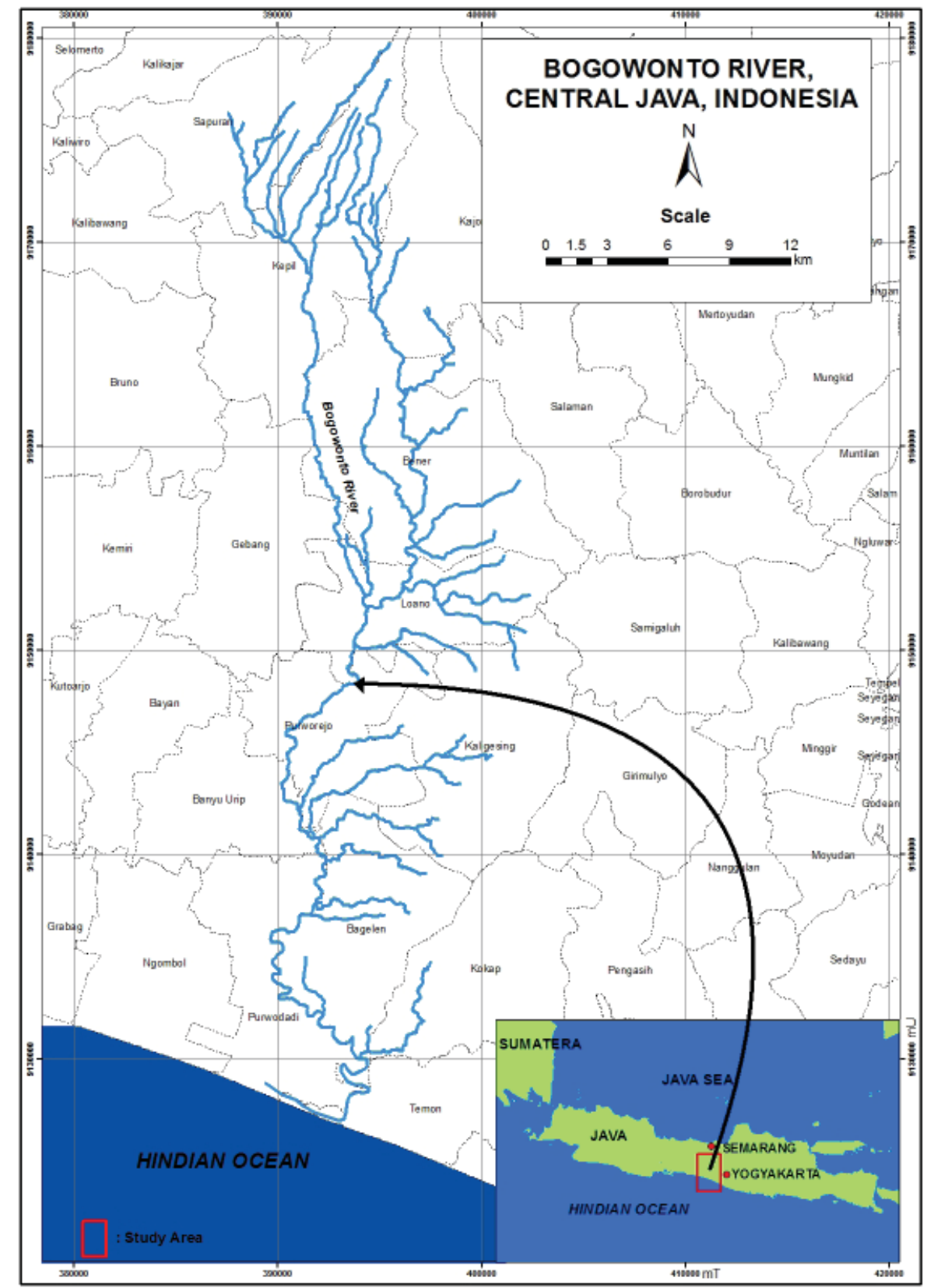

Figure 1. Map of Bogowonto river channels

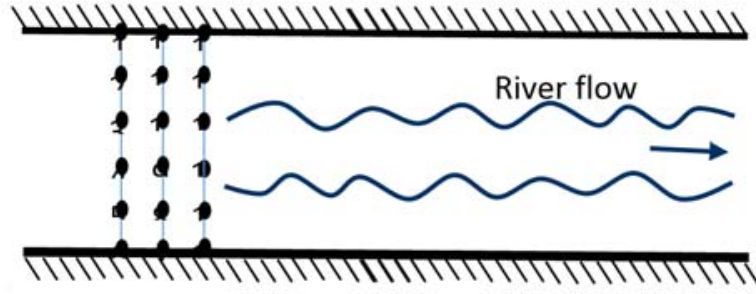

Figure 2. Zig zag stepping as a technique to take riverbed materials

Riverbed sediment grains are taken sequentially starting from gravel $(>2 \mathrm{~cm})$ to bolder $(25.6 \mathrm{~cm})$. Morphometric measurement includes length (A), width (B), and thick (C) of grains as shown in Figure 3

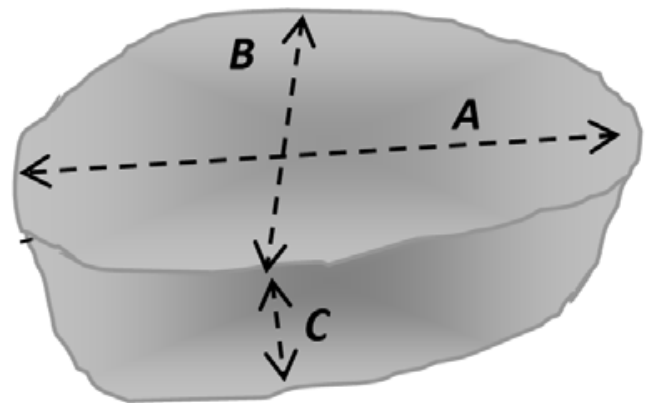

Figure 3. Particle of sediment grain 
Another activity is measuring stone radius to analyse roundness and flatness, which can calculated by the formula of roundness index as follows:

$$
R d=\frac{\sum\left(\frac{r}{R}\right)}{N}=\frac{\sum r}{R N}
$$

Note:

$\mathrm{Rd}=$ Roundness

$\mathrm{r} \quad=$ radius of curvature of the sharpness

$\mathrm{R}=$ maximum radius, radius of the largest inscribed sphere

$\mathrm{N} \quad=$ number of angles

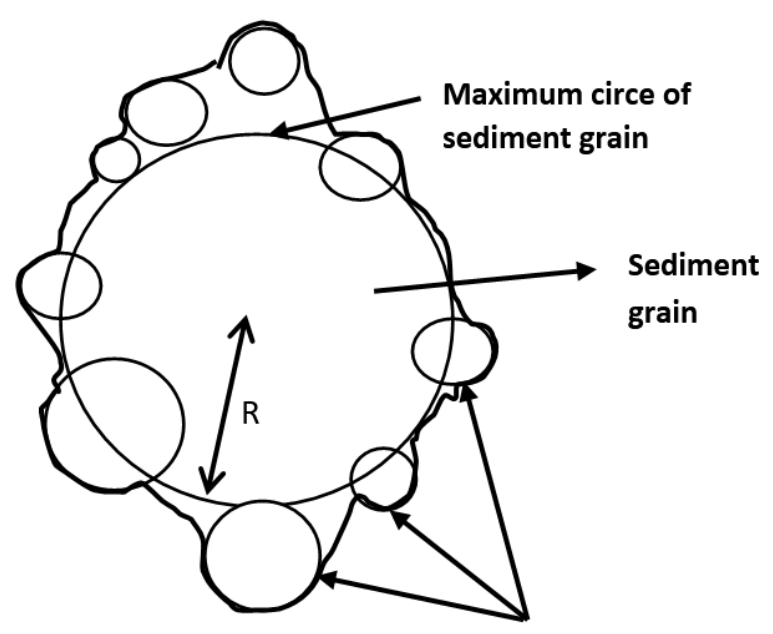

Parts of the radius of the

measured circle stone angle

Result of roundness index calculation (Rd) is then grouped into roundness classes as presented in Table 1 and Figure 5

Tabel 1. Classes of roundness index

\begin{tabular}{cl}
\hline $\begin{array}{c}\text { Interval } \\
\text { (Waddell, 1932) }\end{array}$ & \multicolumn{1}{c}{$\begin{array}{c}\text { Shapes } \\
\text { (Powers, 1953) }\end{array}$} \\
\hline $0.12-0.17$ & Very angular \\
$0.17-0.25$ & Angular \\
$0.25-0.35$ & Sub-angular \\
$0.35-0.49$ & Sub-rounded \\
$0.49-0.70$ & Rounded \\
$0.70-1.00$ & Well Rounded \\
\hline
\end{tabular}

Source : Wadell, 1932 in Reineck and Singh. 1975
From Table 1, sediment grain roundness is visualized in Figure 5.

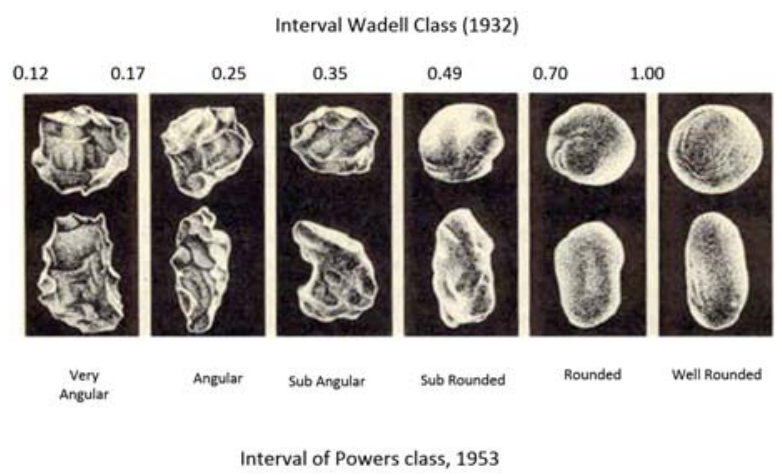

Figure 5. Visualization of roundness index (Wadell, 1932 in Reineck and Singh, 1975)

Sediment grain flatness index is calculated using the formula (2) below:

$$
S p=\frac{(A+B)}{2 C}
$$

Note:

$\mathrm{A}=$ length $(\mathrm{cm})$

$\mathrm{B}=$ width $(\mathrm{cm})$

$\mathrm{C}=$ thickness $(\mathrm{cm})$

Results of flatness index calculation are then classified into flatness classes as presented in Table 2.

Table 2. Flatness Index

\begin{tabular}{ccl}
\hline No & Flatness Index & \multicolumn{1}{c}{ Note } \\
\hline 1 & $1-1.25$ & Equant \\
2 & $1.26-1.67$ & Slightly equant \\
3 & $1.68-2.5$ & Medium \\
4 & $2.6-5$ & Slight platy \\
5 & $>5$ & Platy \\
\hline
\end{tabular}

Source: Cailleux, 1947 in Reineck and Singh. 1975

The result of the analysis of both roundness and flatness is then used to draw the graph of morphometry relationship of sediment grains with the distance from the upper course along 
Bogowonto River, analysis of anomalies that occur in a part of the river and evaluation of anomalies that may occur in the graph. Therefore, it can be evaluated regarding the process or the incidence of what is specified as a reference point to maintain the valleys and cliffs.

\section{Results and Discussions}

\section{Cross-section of Bogowonto River Valley}

Bogowonto River is sourced from the southern flank of Mount Sundoro in the area of Wonosobo regency. It flows to the south through the area of Purworejo regency and end up in the Indian Ocean. The selected research location, Bogowonto river main stream, is approximately $100 \mathrm{~km}$ in length with started from Kepil village in Kepil district in the area of Wonosobo regency as the zero (0) point. The main channel starts from the lower part of the upper part, flows across through a number of different landscapes, from Sindoro volcano, and then flow through the eastern part of Sothern Serayu Structural Mountains, and then alluvial land, sand dunes, and finally the southern beach of Purworejo regency. The results of river valley crosssection measurement from upper course to lower course on every river location at intervals of $\pm 5 \mathrm{~km}$ indicate that changes occur in shape, width and depth of valleys as well as of effective width of river bed on which water flows. As a whole, there is a correlation between the distance from upstream of the river with the valley morphometry of valley river measures along the river. The farther the distance to downstream is, the shallower and wider the river valley, valley shape from $\mathrm{V}$ become $\mathrm{U}$ shape are, as displayed in Table 3 and Figure 6.,

Table 3 and Figure 6 reveal that the river valley and effective river bed respectively from narrow upper course to lower course are getting wider than the valley in the upper course. River in the upper course has more tendency to flow from more inclined to steep volcanic slope (> 25\%), having a high velocity which produces more power, with the dominant process of vertical incision. As a result, the river valley tends to be a deep valley and the valley widening becomes less dominant. The closer to the downstream is the smaller the river gradient will be if compared to that the upper course; hence, it leads to decreasing vertical incision, shallower river valley and more active valley widening. Further, in the area closer to lower course near the beach, the river gradient is smaller $(<5 \%)$, the precipitation process of sedimentary materials is more active, the vertical erosion of river bed is smaller, and the lateral incision is more dominant than the width of the valley in the upstream. 
Table 3. Location of Observation Points on Bogowonto River

\begin{tabular}{|c|c|c|c|c|c|c|c|c|}
\hline \multirow{2}{*}{$\begin{array}{c}\text { Sample } \\
\text { point }\end{array}$} & \multicolumn{2}{|c|}{ Coordinate } & \multicolumn{3}{|c|}{ Location } & \multirow{2}{*}{$\begin{array}{l}\text { Width of the } \\
\text { efective river- } \\
\text { bed (m) }\end{array}$} & \multicolumn{2}{|c|}{ Valley } \\
\hline & $\mathrm{X}$ & Y & Village & District & Regency & & Width (m) & Depth (m) \\
\hline 1 & 391438 & 9168881 & Kepil & Kepil & Wonosobo & 15.3 & 28.7 & 29 \\
\hline 2 & 391851 & 9165307 & Bener & Kepil & Wonosobo & 27.3 & 34.1 & 27 \\
\hline 3 & 391721 & 9164336 & Bener & Kepil & Purworejo & 33.6 & 41.3 & 26 \\
\hline 4 & 391307 & 9162192 & Limbangan & Bener & Purworejo & 48 & 63.7 & 22 \\
\hline 5 & 392412 & 9158305 & Guntur & Bener & Purworejo & 17.3 & 29.7 & 14 \\
\hline 6 & 393330 & 9154641 & Kedungpoh & Loano & Purworejo & 16.2 & 23.1 & 10.2 \\
\hline 7 & 394025 & 9153186 & Maron & Loano & Purworejo & 38.2 & 43.5 & 9.6 \\
\hline 8 & 393692 & 9149771 & Trirejo & Loano & Purworejo & 49.1 & 56.3 & 8.5 \\
\hline 9 & 393020 & 9147979 & Sidomulyo & Purworejo & Purworejo & 13.8 & 30.2 & 8 \\
\hline 10 & 391368 & 9146741 & Kedung Sari & Purworejo & Purworejo & 20.5 & 54.1 & 8.2 \\
\hline 11 & 390421 & 9144194 & Boro Kulon & Banyu Urip & Purworejo & 70.8 & 116.1 & 4.1 \\
\hline 12 & 391162 & 9141778 & Popongan & Banyu Urip & Purworejo & 35 & 49.2 & 3.5 \\
\hline 13 & 392173 & 9139115 & Karangmulyo & Purwodadi & Purworejo & 52.1 & 93.2 & 2.8 \\
\hline 14 & 391110 & 9136749 & Bagelen & Bagelen & Purworejo & 56.2 & 142 & 2.5 \\
\hline 15 & 390044 & 9135716 & Bagelen & Bagelen & Purworejo & 24.2 & 63.6 & 3.8 \\
\hline 16 & 389778 & 9133888 & Guyangan & Purwodadi & Purworejo & 31 & 46.7 & 5.1 \\
\hline 17 & 391453 & 9132200 & Bapangsari & Purwodadi & Purworejo & 21.7 & 44.9 & 3 \\
\hline 18 & 393696 & 9131073 & Karangsari & Purwodadi & Purworejo & 42.5 & 60.5 & 3.5 \\
\hline 19 & 394292 & 9129967 & Dadirejo & Bagelen & Purworejo & 32.8 & 52.1 & 2.5 \\
\hline 20 & 393796 & 9127155 & Jangkaran & Temon & Kulonprogo & 180 & 180 & 2,0 \\
\hline
\end{tabular}

Source : Field survey, Mei, 2014

Note: No. 19 and 20 have basic materials of rough to soft sand 


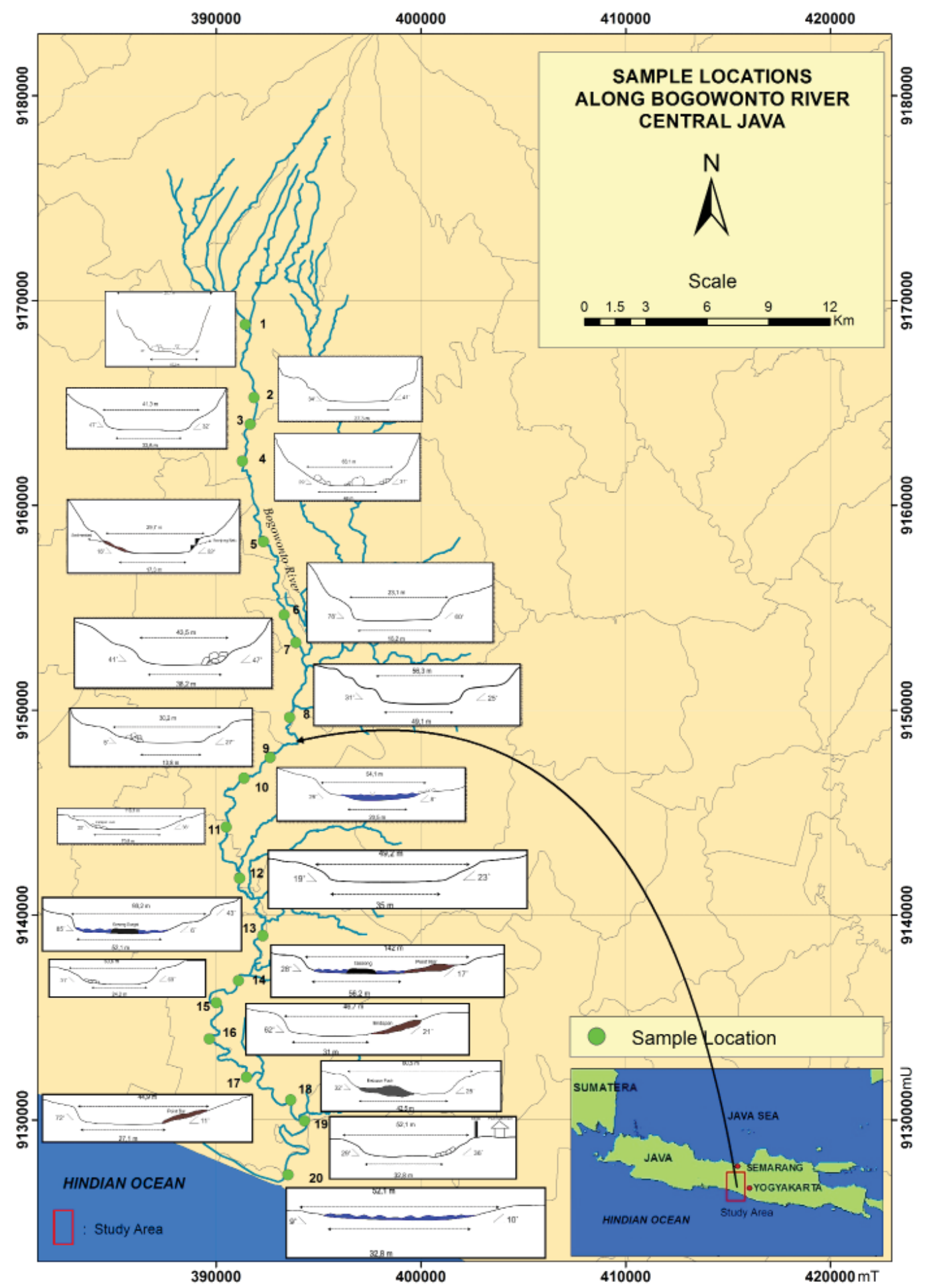

Figure 6. The cross section of each sample location Roundness and Flatness of Sedimentary Grain as Basic Indicator Management of River Valley Environment

One of determining factor for changes on sedimentary particle roundness and flatness is sediment transport distance from upper to lower river courses. The field data measures of roundness and flatness indexes of river bed at very $5 \mathrm{~km}$ distance is presented in Table 4 . 
Table 4. Morphometry Value Sediment Grain Particles of Bogowonto Riverbed

\begin{tabular}{cccccc}
\hline & \multirow{2}{*}{$\begin{array}{c}\text { Distance (from upper to } \\
\text { No. }\end{array}$} & \multicolumn{2}{c}{ Coordinate } & & \\
\cline { 3 - 4 } & $(\mathrm{Km})$ & $\mathrm{mT}$ & $\mathrm{mU}$ & Roundness & Flatness \\
\hline 1 & 0 & 391438 & 9168881 & 0.351 & 1.551 \\
2 & 5 & 391851 & 9165307 & 0.356 & 1.668 \\
3 & 10 & 391721 & 9164336 & 0.360 & 1.716 \\
4 & 15 & 391307 & 9162192 & 0.413 & 1.732 \\
5 & 20 & 392412 & 9158305 & 0.412 & 1.733 \\
6 & 25 & 393330 & 9154641 & 0.424 & 1.815 \\
7 & 30 & 394025 & 9153186 & 0.408 & 1.853 \\
8 & 35 & 393692 & 9149771 & 0.409 & 1.903 \\
9 & 40 & 393020 & 9147979 & 0.364 & 1.953 \\
10 & 45 & 391368 & 9146741 & 0.370 & 1.896 \\
11 & 50 & 390421 & 9144194 & 0.307 & 1.664 \\
12 & 55 & 391162 & 9141778 & 0.310 & 1.714 \\
14 & 60 & 391110 & 9136749 & 0.459 & 1.902 \\
15 & 65 & 390044 & 9135716 & 0.461 & 2.049 \\
16 & 70 & 389778 & 9133888 & 0.472 & 2.079 \\
17 & 75 & 391453 & 9132200 & 0.470 & 2.188 \\
18 & 80 & 393696 & 9131073 & 0.481 & 2.352 \\
\hline $50 u r$ & & & & &
\end{tabular}

Source: Field measurement, June 2014

Furthermore, to determine the relationship between transport distance sediment grains with roundness index and flatness index is done by making a connection between the two variable graph distance with variable such as presented in the form of regression and bar graph as presented in Figure 7 and Figure 8.

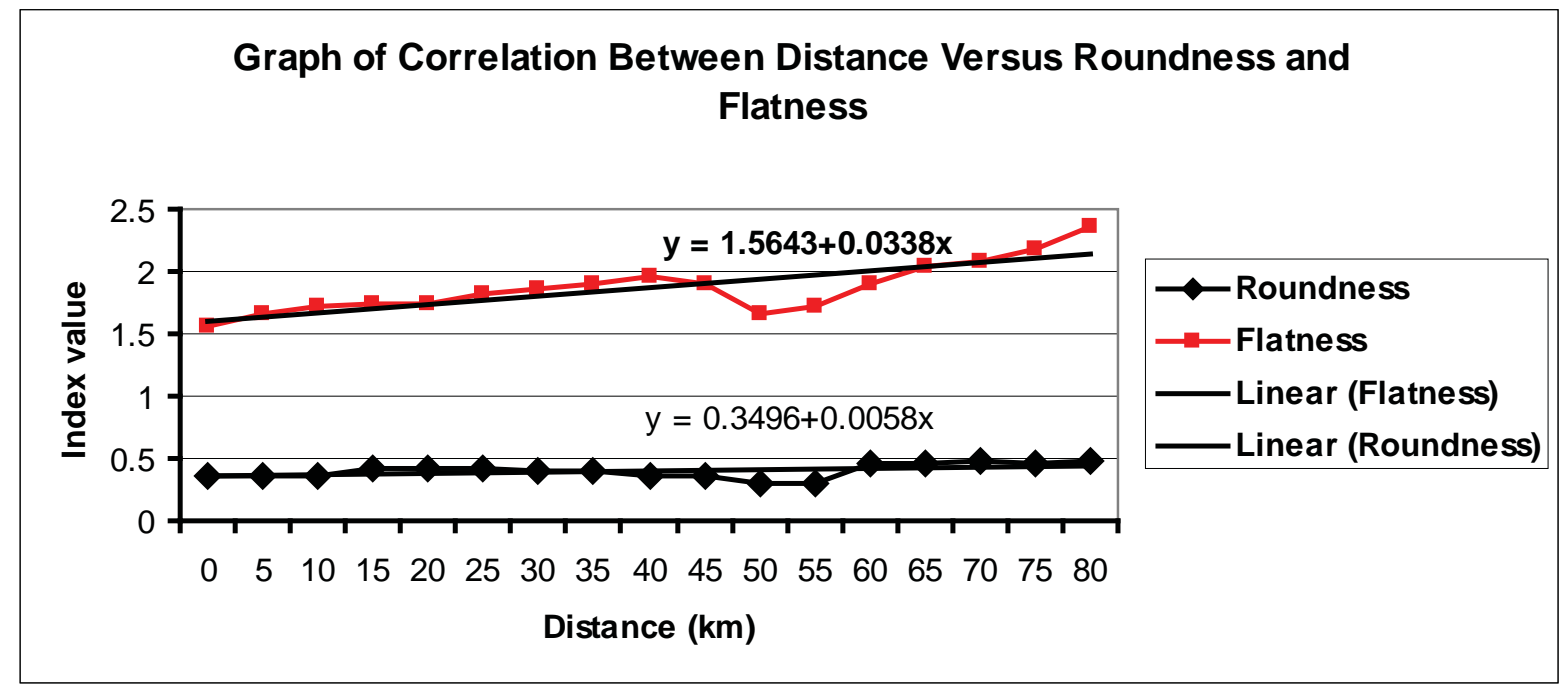

Figure 7. Relationship between transported distance of sedimentary grains from upper course and roundness and flatness indexes. 


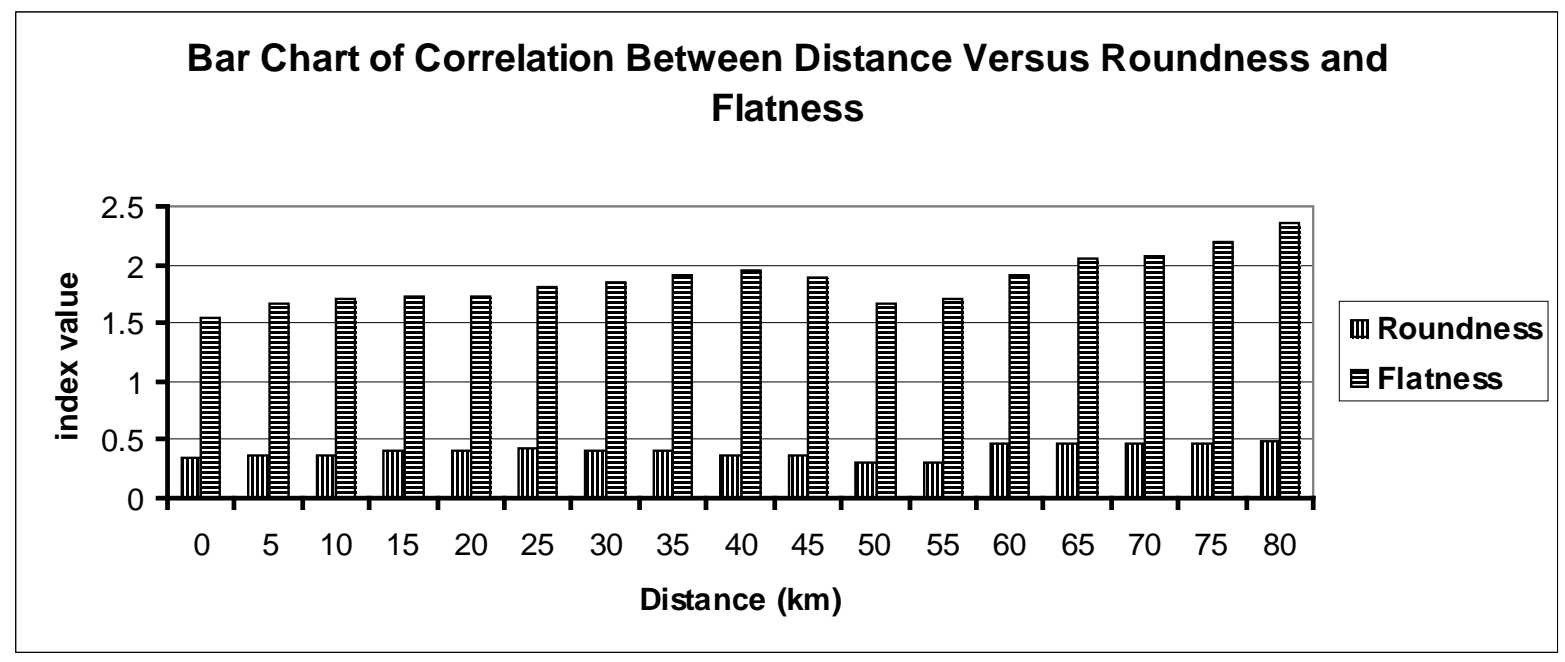

Figure 8. Bar chart of correlation between distance versus roundness and flatness index.

Based on the results of simple regression analysis shows that the index value roundness sediment grains have a tendency to rise close to 1 , in line with the transport distance from the zero point of the river upstream. From the two graphs both simple linear graph (Figure 7) as well as a bar chart (Figure 8) shows the occurrence of anomalous roundness index value at the point 9 and 12 range of \pm 55-65 $\mathrm{km}$ ) from upstream. At such distances index roundness value changes significantly, form roundness index of 0.409 at point 8 become 0364, 0307 and 0310 respectively, and at the end of this segment (point 14) downstream become higher (0459) than before. Results showed that it is because the river segment (point 9, 10, 11, and 12) flows offer the river bottom that composed of breccia rock along about $10 \mathrm{~km}$, and also river valley along that segment become wider than the valley width before and after the sites.
As presented in Figure 7 and 8 above, regression and bar chart of the relationship between the value of flatness index and transportation distances have a positive correlation. As it is occur in the value of roundness index, the anomalous of flatness index have also occurred at points of 9 and 12 (distance of \pm $55-65 \mathrm{~km}$ ), where the flatness index has being decrease in flatness index. At the first point of measuring the flatness index, the value of the flatness index is low. In gradual, the farther the sedimentary material transported towards downstream, the greater the flatness index value is. But at the distance of about $55-60$ $\mathrm{km}$ there is a change the flatness index value goes down, after that value of flatness index increase after the distance farther than $65 \mathrm{~km}$ to the downstream. The results showed that the distance of the river segment about 55-65 $\mathrm{km}$ range ( $\pm 10 \mathrm{~km}$ length), the river bottom consist of coarse and sharp angle of breccia grain as soon in Figure 9. 


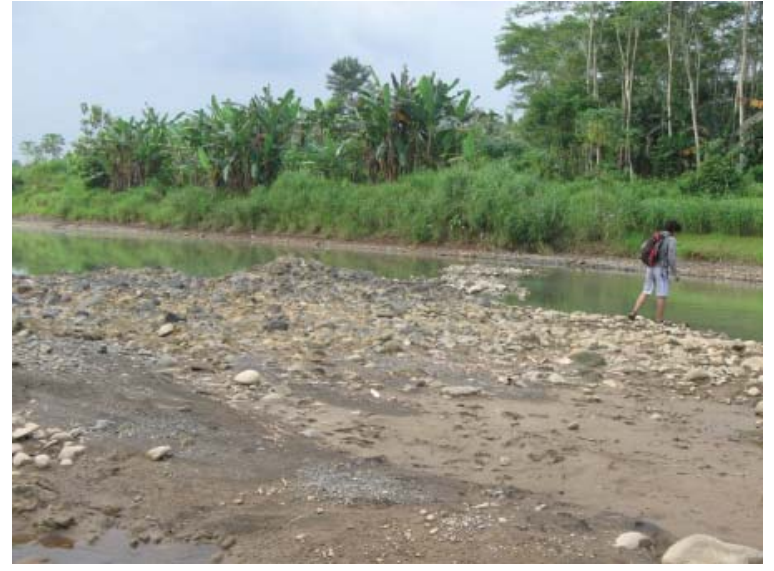

A

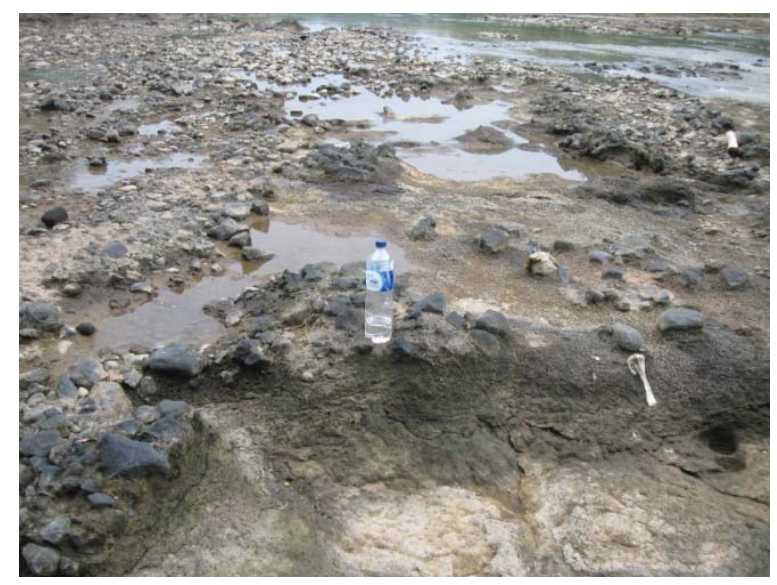

B

Figure 9 River bedrock and materials at point 11 (A) and point 13 (B) which composed of is basically loose sediment grains of breccia

Coarse and sharp river bed materials grains cause the sedimentary grains is sharply decreased in the value of roundness and flatness index. Both in that location and the previous location, changing in roundness and flatness indexes are not only resulted from the addition of new materials from both sides of river valley but it also supported by rock material from river bottom itself.

\section{Conclusion}

Some conclusions that can be drawn from the results of this research are (1) there is morphometry relationship between sediment grain and the distance of transports grain of sediment. The farther the sediment transported from upper course is, the greater the roundness index value of the grains will be approaching the value of 1 (one). Furthermore, the greater the distance of transport material, the higher the value of flatness index (more than 1); (2) there is a correlation between morphometry of river valley and the distance from upper course to lower course. The farther the distance to lower course, the wider the river valley is. Meanwhile, the farther the distance to lower course, the shallower the depth of the river bottom; (3) there is anomalous morphometry of sediment grains at point 11 (X : 390 421, Y: 9144194) and point 12 (X : 391162, Y: 9141778), which is caused by the condition of the river bed materials which consist of loose deposits of breccia in Bogowonto Riverbed; (4) the anomalous value of roundness and flatness index that happen within the river valley can be implemented as a basic indicator management of river valley environment.

\section{Acknowledgement}

By the completion of the research reports and draft of the paper, the researchers deliver his gratitude to Cahyo Nur Rahmat Nugroho, Zulhan Effendy, Yusuf Wahyu Ardianto, Aldhila Gusta, Haviz, Igor Yoga B, Brianardi W, Wahyu Hidayat, M. Ngainul, Adrea Farandika, and Rinaldi Saputro who have fully assisted the researchers in collecting the samples of sediment grains in the field. Furthermore, they also give contribution in analysing the morphometry of sediment grain (length, width and thickness) and measurement of the radius of circle of sedimentary stone. 


\section{References}

Adamczak, Sdanislaw, Janecki, Stepein, and Krzysztof, 2011. Recent trends in Measurements of Sphericity. Annual of DAM \& Proceeding, Jan 2011

Baotian Pan, Hongli Pang, Di Zhang, Qingyu Guan, Lei Wang, Fuqiang Li, Wenqian Guan, Ao Cai, Xiazhong Sun. 2015. Sediment grain-size characteristics and its source implication in the Ningxia-Inner Mongolia sections on the upper reaches of the Yellow River. Geomorphology 246 (2015) 255-262

Barret P, 2010. The Shape of Rock Particle, a Critical Review. Sedimentology Vol 27. Issue 3

Bloff, Simon J, Pye, and Kunneth, 2008 Particle Shape : A Review and New Method of Characterization and Classification. Sedimentology. Vol 55. Issue 1

Boggs, S. Jr., 1987, Petrology of Sedimentary Rocks, Mac-millan Publishing Company, New York.

Darrel Maddy, Mark G. Macklin and Jamie C. Woodward. 2001. River Basin Sediments System : Archive of Environmental change. Balkema Publisher. Tokyo

Dunatnu, Dan, Niculitja, Mihai, Condoraci, and Danniel, 2011. Downstream variation in the Pebble Morphometry of the Trotus River, Eastern Carpthrans (Rumania). Forum Geographia, Vol.10 Issues 2

Gunther R. Drevin. 2006. Computational Methods for the Determination of Roundness of Sedimentary Particles. Mathematical Geology, Vol. 38, No. 7, November 2006

Jeffrey W. Bullard and Edward J. Garboczi. 2013. Defining shape measures for 3D star-shaped particles: Sphericity, roundness, and dimensions. Powder Technology 249 (2013) 241-252

Koeli Ghoshal and Debasish PAL. 2014. Grain-size distribution in suspension over a sandgravel bed in open channel flow. International Journal of Sediment Research Vol. 29 (2014) 184-194

Krumbein, WC. 1941a. Measurement and geologic significance of shape and roundness of sedimentary particles. Jour. Sed. Petr.

Krumbein, WC. 1941b. The effects of abrasion on the size, shape, and roundness of rock fragments. Jour. Geol.

Mark W. Smith. 2014. Roughness in the Earth Sciences. Earth-Science Reviews 136 (2014) 202-225

Morisawa, M., 1968. Streams, Their Dynamic and Morphology. McGraw-Hill Book Company. London

Reineck, H.E., and Singh, I.B. 1975. Depositional Sedimentary Environments, Springer-Verlag, New York.

Ro Charlton. 2008. Fundamental of Fluvial Geomorphology. Roudlete, USA.

Stanly J., Jean Daniel,, and S. Victorial, 2006. Inconsisten Grain Roundness and Sphericity Trend and the Valley Wall Influx Factor Between Alpens Shore and Lake Shore, S.E France. Journal of Coastal Research, Vol 22 Issues 3

Strahler, A.N., and A.H. Strahler, 1978, Modern Physical Geography.John wiley and Sons, New York.

Thornbury, W.D., 1958, Principles of Geomorphology, John Wiley and Sons, New York. 
Yuichi Hayakawa and Takashi Oguchi. 2005. Evaluation of gravel sphericity and roundness based on surface-area measurement with a laser scanner. Computers \& Geosciences 31 (2005) 735-741

Verstappen, H.Th., 1983, Applied Geomorphology, Geomorphological Survey for Environmental Development, Elsevier, Amsterdam, the Netherlands 